\title{
Maternal Hypothyroidism and Developing Hyperhomocysteinemia
}

\author{
Ahmed R.G* \\ Division of Anatomy and Embryology, Zoology Department, Faculty of Science, Beni-Suef University, Beni- \\ Suef, Egypt
}

*Corresponding Author: Ahmed R.G, Division of Anatomy and Embryology, Zoology Department, Faculty of Science, Beni-Suef University, Beni-Suef, Egypt, Email: ahmedragab08@gmail.com

\section{BRIEF REPORT}

A regular transfer of thyroid hormones (THs) from the placenta to fetuses/neonates is needed for the development(El-bakry et al., 2010; Ahmed, 2011, 2012a,b, 2013, 2014, 2015a-c, 2016a-d, 2017a-v, 2018a-1; Ahmed and Ahmed, 2012; Ahmed et al., 2008; 2010; 2012; 2013a,b, 2014, 2015a,b, 2018a,b; Ahmed and Incerpi, 2013; Van Hercket al., 2013; Ahmed and ElGareib, 2014,Incerpi et al., 2014; Candelotti et al., 2015; De Vito et al., 2015; El-Ghareeb et al., 2016; Ahmed and El-Gareib, 2017), particularly the levels of homocysteine and the concentrations of lipid profile (Catargi et al., 2009; Saleh, 2015).In addition, the number of studies has displayed relations between the hypothyroidism and increased the levels of homocysteine (hyperhomocysteinemia), lipid abnormalities, anda dynamic atherogenic state(Catargi et al., 2009; Yang et al., 2015).There are associations between the clinical hypothyroidism (Colleran et al., 2005) orovert hypothyroidism (Sengül et al., 2004) with the hyperhomocysteinemia. This abnormal state can increase the risk of atherosclerotic heart diseases (cardiovascular diseases) such as coronary artery disease (CAD) (Sengül et al., 2004; Catargi et al., 2009; Bamashmooset al., 2013; Morris et al., 2013). More importantly, Yang et al. (2015) reported that hyperhomocysteinemia-induced with hypothyroidism or subclinical hypothyroidism can increase the homeostatic index of insulin resistance (HOMAIR).IR can perturb the insulin pathway, glucose metabolism, adipokine production, and lipogenesis in several organs such as the adipose tissue, muscles and liver (Schachter et al., 2003; Wang et al., 2005; Li et al., 2008; Yilmaz et al., 2008; Yang et al., 2015). Several studies have demonstrated that IR can cause dysfunction in the vascular endothelium, initiate atherosclerosis and increase the risk of CAD (Bornfeldt and Tabas, 2011; Karrowni et al., 2013; He et al., 2010; Li et al., 2013). Hyperhomocysteinemia can increase the cardiovascular diseases by several mechanisms as the following (Ji et al., 2004; Wang et al., 2005; Edirimanne et al., 2007; Cui et al., 2008; Chiang et al., 2011; Wang et al., 2012; Deyneli et al., 2014; Yang et al., 2015): (1) oxidative stress; (2) platelet aggregation; (3) endoplasmic reticulum stress; (4) endothelial dysfunction; (5) smooth muscle cell proliferation; and (6) augmenting the responsiveness of monocytes to inflammatory stimuli. However, the underlying effects of hypothyroidism and hyperhomocysteinemia on the IR remain indistinguishable.

From the above investigations, it is worth mentioning that the present report throws up some vital observations. The regular levels of maternal THs during the pregnancy may regulate the levels of homocysteine and the developing fetuses and neonates. In addition, the disorders in the activities of THs (hypothyroidism) during the gestation may cause hyperhomocysteinemia and increase the risk of atherosclerosis, strokes and heart attacks. This disruption may delay the fetal and neonatal development. In general, this report suggested that pregnant dams should be encouraged to evade the hypothyroxinaemia and hyperhomocysteinemia by following the profile of thyroid gland and the levels of homocysteine during the gestation. More information is wanted to evaluate these investigations and to follow the destructive effects of maternofetal thyroid disorders and hyperhomocysteinemiaon the IR and fetal and neonatal development. In addition, the connection between the developmental and biochemical studies is required. 


\section{REFERENCES}

[1] Ahmed, O.M., Abd El-Tawab, S.M., Ahmed, R.G., 2010. Effects of experimentally induced maternal hypothyroidism and hyperthyroidism on the development of rat offspring: I- The development of the thyroid hormonesneurotransmitters and adenosinergic system interactions. Int. J. Dev. Neurosci. 28, 437-454.

[2] Ahmed, O.M., Ahmed, R.G., 2012. Hypothyroidism. In A New Look At Hypothyroidism. Dr. D. Springer (Ed.), ISBN:978-953-51-0020-1), In Tech Open Access Publisher, Chapter 1, pp. 1-20.

[3] Ahmed, O.M., Ahmed, R.G., El-Gareib, A.W., El-Bakry, A.M., Abd El-Tawaba, S.M., 2012. Effects of experimentally induced maternal hypothyroidism and hyperthyroidism on the development of rat offspring: II-The developmental pattern of neurons in relation to oxidative stress and antioxidant defense system. Int. J. Dev. Neurosci. 30, 517-537.

[4] Ahmed, O.M., El-Gareib, A.W., El-bakry, A.M., Abd El-Tawab, S.M., Ahmed, R.G., 2008. Thyroid hormones states and brain development interactions. Int. J. Dev. Neurosci. 26(2), 147-209. Review.

[5] Ahmed, R.G., 2011. Perinatal 2, 3, 7, 8tetrachlorodibenzo-p-dioxin exposure alters developmental neuroendocrine system. Food Chem. Toxicology, 49, 1276-1284.

[6] Ahmed, R.G., 2012a. Maternal-newborn thyroid dysfunction. In the Developmental Neuroendocrinology, pp. 1-369. Ed R.G. Ahmed. Germany: LAP LAMBERT Academic Publishing GmbH \& Co KG.

[7] Ahmed, R.G., 2012b. Maternal-fetal thyroid interactions, Thyroid Hormone, Dr. N.K. Agrawal (Ed.), ISBN: 978-953-51-0678-4, In Tech Open Access Publisher, Chapter 5, pp. 125-156.

[8] Ahmed, R.G., 2013. Early weaning PCB 95 exposure alters the neonatal endocrine system: thyroid adipokine dysfunction. J. Endocrinol. 219 (3), 205-215.

[9] Ahmed, R.G., 2014. Editorial: ¿Do PCBs modify the thyroid-adipokine axis during development? Annals Thyroid Res. 1(1), 11-12.

[10] Ahmed, R.G., 2015a. Chapter 1: Hypothyroidism and brain development. In advances in hypothyroidism treatment.Avid Science Borsigstr.9, 10115 Berlin, Berlin, Germany. Avid Science Publications level 6, Melange Towers, Wing a, Hitec City, Hyderabad, Telangana, India. pp. 1-40.

[11] Ahmed, R.G., 2015b. Hypothyroidism and brain developmental players. Thyroid Research J. 8(2), 1-12.
[12] Ahmed, R.G., 2015c. Editorials and Commentary: Maternofetal thyroid action and brain development. J. of Advances in Biology; 7(1), 1207-1213.

[13] Ahmed, R.G., 2016a. Gestational dexamethasone alters fetal neuroendocrine axis. Toxicology Letters, 258, 46-54.

[14] Ahmed, R.G., 2016b. Neonatal polychlorinated biphenyls-induced endocrine dysfunction. Ann. Thyroid. Res. 2 (1), 34-35.

[15] Ahmed, R.G., 2016c. Maternal iodine deficiency and brain disorders. Endocrinol. Metab.Syndr.5, 223.http ://dx.doi.org/ 10.4172 / 2161-1017.1000223.

[16] Ahmed, R.G., 2016d. Maternal bisphenol A alters fetal endocrine system: Thyroid adipokine dysfunction. Food Chem. Toxicology, 95, 168-174.

[17] Ahmed, R.G.,2017 a. Developmental thyroid diseases and GABAergic dysfunction. EC Neurology 8.1, 02-04.

[18] Ahmed, R.G., 2017b. Hyperthyroidism and developmental dysfunction. Arch Med. 9, 4 .

[19] Ahmed, R.G.,2017c. Anti-thyroid drugs may be at higher risk for perinatal thyroid disease. EC Pharmacology and Toxicology 4.4, 140-142.

[20] Ahmed, R.G.,2017d. Perinatal hypothyroidism and cytoskeleton dysfunction. Endocrinol MetabSyndr 6, 271.doi:10.4172/2161-1017.10 00271

[21] Ahmed, R.G.,2017e. Developmental thyroid diseases and monoaminergic dysfunction. Advances in Applied Science Research 8(3), 01-10.

[22] Ahmed, R.G.,2017f. Hypothyroidism and brain development.J. Anim Res Nutr.2(2), 13.

[23] Ahmed, R.G.,2017g. Antiepileptic drugs and developmental neuroendocrine dysfunction: Every why has A Wherefore.Arch Med 9(6), 2.

[24] Ahmed, R.G.,2017h. Gestational prooxidantantioxidant imbalance may be at higher risk for postpartum thyroid disease. EndocrinolMetabSyndr 6, 279. doi:10.4172 / 2161-1017.1000279.

[25] Ahmed, R.G.,2017i. Synergistic actions of thyroid-adipokines axis during development. EndocrinolMetabSyndr 6,280. doi:10.4172/ $2161-1017.1000280$.

[26] Ahmed, R.G.,2017j. Thyroid-insulin dysfunction during development. International Journal of Research Studies in Zoology 3(4), 73-75. DOI: http://dx.doi.org/10.20431/2454941X.0304010.

[27] Ahmed, R.G.,2017k. Developmental thyroid diseases and cholinergic imbalance. International Journal of Research Studies in Zoology 3(4), 70-72. DOI: http:// dx.doi. org/ 10.20431/2454-941X.0304009. 
[28] Ahmed, R.G.,20171. Thyroid diseases and developmental adenosinergic imbalance.Int $\mathrm{J}$ ClinEndocrinol 1(2), 053-055.

[29] Ahmed, R.G., 2017m.Maternal anticancer drugs and fetal neuroendocrine dysfunction in experimental animals. EndocrinolMetabSyndr 6, 281.doi:10.4172/2161-1017.1000281.

[30] Ahmed, R.G.,2017n. Letter: Gestational dexamethasone may be at higher risk for thyroid disease developing peripartum. Open Journal Of Biomedical \& Life Sciences (Ojbili) 3(2), 01-06.

[31] Ahmed, R.G., 2017o.Deiodinases and developmental hypothyroidism. EC Nutrition 11.5, 183-185.

[32] Ahmed, R.G., 2017p.Maternofetal thyroid hormones and risk of diabetes. Int. J. of Res. Studies in Medical and Health Sciences 2(10), 18-21.

[33] Ahmed, R.G., 2017r.Association between hypothyroidism and renal dysfunctions. International Journal of Research Studies in Medical and Health Sciences 2(11), 1-4.

[34] Ahmed, R.G., 2017s.Maternal hypothyroidism and lung dysfunction. International Journal of Research Studies in Medical and Health Sciences 2(11), 8-11.

[35] Ahmed, R.G., 2017t.Endocrine disruptors; possible mechanisms for inducing developmental disorders. International journal of basic science in medicine (IJBSM)2(4), 157160.

[36] Ahmed, R.G., 2017u.Maternal thyroid hormones trajectories and neonatal behavioral disorders. ARC Journal of Diabetes and Endocrinology 3(2), 18-21.

[37] Ahmed, R.G., 2017v.Maternal thyroid dysfunction and neonatal cardiac disorders. Insights Biol Med. 1, 092-096.

[38] Ahmed, R.G., 2018a. Maternal hypothyroidism and neonatal testicular dysfunction. International Journal of Research Studies in Medical and Health Sciences 3(1), 8-12.

[39] Ahmed, R.G.,2018b. Maternal hypothyroidism and neonatal depression: Current perspective. International Journal of Research Studies in Zoology 4(1), 6-10. DOI: http://dx.doi.org/ 10.20431/2454-941X .0401002.

[40] Ahmed, R.G.,2018c. Non-genomic actions of thyroid hormones during development. App ClinPharmacolToxicol: ACPT-108. DOI: 10.29011/ACPT-109. 100008.

[41] Ahmed, R.G.,2018d. Maternal thyroid function and placental hemodynamics. ARC Journal of Animal and Veterinary Sciences 4(1), 9-13. DOI: http://dx.doi.org/10.20431/2455-2518. 04 01002.

[42] Ahmed, R.G., 2018e.Interactions between thyroid and growth factors during development.
ARC Journal of Diabetes and Endocrinology 4(1), 1-4. DOI: http:/ /dx.doi .org/ 10. 20431/ 2455-5983.0401001.

[43] Ahmed, R.G.,2018f. Maternal thyroid hormones and neonatal appetite. ARC Journal of Nutrition and Growth 4(1), 18-22. DOI: http://dx.doi.org/10.20431/2455-2550.0401005.

[44] Ahmed, R.G.,2018g. Genomic actions of thyroid hormones during development. ARC Journal of Diabetes and Endocrinology 4(1), 58. DOI: http://dx.doi.org/10.20431/2455-59 83 . 0401002.

[45] Ahmed, R.G.,2018h. Dysfunction of maternal thyroid hormones and psychiatric symptoms.American Research Journal of Endocrinology. 2(1), 1-6.

[46] Ahmed, R.G.,2018i. Is there a connection between maternal hypothyroidism and developing autism spectrum disorders? ARC Journal of Neuroscience 3(1), 5-8.DOI: http: //dx.doi.org/10.20431/2456-057X.0301002.

[47] Ahmed, R.G.,2018j.Maternal thyroid dysfunctions and neonatal bone maldevelopment.American Research Journal of Endocrinology (in press) xx-Xxx.

[48] Ahmed, R.G., 2018k. Maternal thyroid disorders and risk of neonatal seizure: Current perspective. ARC Journal of Neuroscience (in press) $\mathrm{xx}-\mathrm{xx}$.

[49] Ahmed, R.G., 20181. Gestational dioxin acts as developing neuroendocrine-disruptor. EC Pharmacology and Toxicology (in press) xx-xx.

[50] Ahmed, R.G., Abdel-Latif, M., Ahmed F., 2015a.Protective effects of GM-CSF in experimental neonatal hypothyroidism. International Immunopharmacology 29, 538543.

[51] Ahmed, R.G., Abdel-Latif, M., Mahdi, E., ElNesr, K., 2015b. Immune stimulation improves endocrine and neural fetal outcomes in a model of maternofetal thyrotoxicosis. Int. Immunopharmacol. 29, 714-721.

[52] Ahmed, R.G., Davis, P.J., Davis, F.B., De Vito, P., Farias, R.N., Luly, P., Pedersen, J.Z., Incerpi, S., 2013a. Nongenomic actions of thyroid hormones: from basic research to clinical applications. An update. Immunology, Endocrine \& Metabolic Agents in Medicinal Chemistry, 13(1), 46-59.

[53] Ahmed, R.G., El-Gareib, A.W. 2014.Lactating PTU exposure: I- Alters thyroid-neural axis in neonatal cerebellum. Eur. J. of Biol. and Medical Sci. Res. 2(1), 1-16.

[54] Ahmed, R.G., El-Gareib, A.W., 2017.Maternal carbamazepine alters fetal neuroendocrinecytokines axis. Toxicology 382, 59-66.

[55] Ahmed, R.G., El-Gareib, A.W., Incerpi, S., 2014. Lactating PTU exposure: II- Alters 
thyroid-axis and prooxidant-antioxidant balance in neonatal cerebellum. Int. Res. J. of Natural Sciences 2(1), 1-20.

[56] Ahmed, R.G., El-Gareib, A.W., Shaker, H.M., 2018a.Gestational 3,3',4,4',5-pentachlorobiphenyl (PCB 126) exposure disrupts fetoplacental unit: Fetal thyroid-cytokines dysfunction. Life Sciences 192, 213-220.

[57] Ahmed, R.G., Walaa G.H., Asmaa F.S., 2018b.Suppressive effects of neonatal bisphenol A on the neuroendocrine system. Toxicology and Industrial Health Journal (in press).

[58] Ahmed, R.G., Incerpi, S., 2013. Gestational doxorubicin alters fetal thyroid-brain axis. Int. J. Devl. Neuroscience 31, 96-104.

[59] Ahmed, R.G., Incerpi, S., Ahmed, F., Gaber, A., 2013b. The developmental and physiological interactions between free radicals and antioxidant: Effect of environmental pollutants. J. of Natural Sci. Res. 3(13), 74-110.

[60] Bamashmoos, S.A., Al-Nuzaily, M.A., AlMeeri, A.M., Ali, F.H., 2013. Relationship between total homocysteine, total cholesterol and creatinine levels in overt hypothyroid patients. Springerplus.30, 423.

[61] Bautista, L.E., Arenas, I.A., Peñuela, A., Martínez, L.X., 2002. Total, plasma homocysteine level and risk of cardiovascular disease: a meta-analysis of prospective cohort studies. J ClinEpidemiol. 55, 882-887.

[62] Bornfeldt, K.E., Tabas, I., 2011. Insulin resistance, hyperglycemia, and aterosclerosis. Cell Metab. 14, 575-585.

[63] Candelotti, E., De Vito, P., Ahmed, R.G., Luly, P., Davis, P.J., Pedersen, J.Z., Lin, H-Y., Incerpi, I., 2015. Thyroid hormones crosstalk with growth factors: Old facts and new hypotheses. Immun., Endoc. \&Metab. Agents in Med. Chem., 15, 71-85.

[64] Catargi, B., Parrot-Roulaud, F., Cochet, C., Ducassou, D., Roger, P., Tabarin, A., 2009.Homocysteine, hypothyroidism, and effect of thyroid hormone replacement. Thyroid 9(12), 1163-1166.

[65] Chiang, J.K., Sung, M.L., Yu, H.R., Chang, H.I., Kuo, H.C., Tsai, T.C., 2011. Homocysteine induces smooth muscle cell proliferation through differential regulation of cyclins A and D1 expression. J Cell Physiol. 226, 1017-1026.

[66] Colleran, K.M., Romero, L.A., Upton, D.A., Burge, M.R., 2005. Methimazole-induced hypothyroidism paradoxically decreases homocysteine. Clinical and Experimental Metab. 54(4), 460-465.

[67] Cui, R., Moriyama, Y., Koike, K.A., Date, C., Kikuchi, S., Tamakoshi, A., 2008. Serum total homocysteine concentrations and risk of mortality from stroke and coronary heart disease in Japanese: The JACC study. Atherosclerosis. 198, 412-418.

[68] De Vito, P., Candelotti, E., Ahmed, R.G., Luly, P., Davis, P.J., Incerpi, S., Pedersen, J.Z., 2015.Role of thyroid hormones in insulin resistance and diabetes. Immun., Endoc. \& Metab. Agents in Med. Chem., 15, 86-93.

[69] Deyneli, O., Akpınar, I.N., Meriçliler, O.S., Gözü, H., Yıldız, M.E., Akalın, N.S., 2014. Effects of levothyroxine treatment on insulin sensitivity, endothelial function and risk factors of atherosclerosis in hypothyroid women. Ann Endocrinol (Paris) 75, 220-226.

[70] Edirimanne, V.E., Woo, C.W., Siow, Y.L., Pierce, G.N., Xie, J.Y., 2007. Homocysteine stimulates NADPH oxidase-mediated superoxide production leading to endothelial dysfunction in rats. Can J PhysiolPharmacol. 85, 1236-1247.

[71] El-bakry, A.M., El-Ghareeb, A.W.,Ahmed, R.G., 2010.Comparative study of the effects of experimentally-induced hypothyroidism and hyperthyroidism in some brain regions in albino rats.Int. J. Dev. Neurosci. 28, 371-389.

[72] El-Ghareeb, A.A., El-Bakry, A.M., Ahmed, R.G., Gaber, A., 2016.Effects of zinc supplementation in neonatal hypothyroidism and cerebellar distortion induced by maternal carbimazole. Asian Journal of Applied Sciences 4(04), 1030-1040.

[73] He, L., Zeng, H., Li, F., Feng, J., Liu, S., Liu, J., 2010. Homocysteine impairs coronary artery endothelial function by inhibiting tetrahydrobiopterin in patients with hyperhomocysteinemia. Am J PhysiolEndo crinolMetab.299, E1061-1065.

[74] Incerpi, S., Hsieh, M-T., Lin, H-Y., Cheng, GY., De Vito, P., Fiore, A.M., Ahmed, R.G., Salvia, R., Candelotti, E., Leone, S., Luly, P., Pedersen, J.Z., Davis, F.B., Davis, P.J., 2014. Thyroid hormone inhibition in L6 myoblasts of IGF-I-mediated glucose uptake and proliferation: new roles for integrin $\alpha v \beta 3$. Am. J. Physiol. Cell Physiol. 307, C150-C161.

[75] Jim, C., Kaplowitz, N., 2004.Hyperhom-o cysteinemia, endoplasmic reticulum stress, and alcoholic liver injury. World J Gastroenterol. 10, 1699-1708.

[76] Karrowni, W., Li, Y., Jones, P.G., Cresci, S., Abdallah, M.S., Lanfear, D.E., 2013. Insulin resistance is associated with significant clinical atherosclerosis in nondiabetic patients with acute myocardial infarction. Arterioscler ThrombVasc Biol. 33, 2245-2251.

[77] Li, Y., Jiang, C., Xu, G., Wang, N., Zhu, Y., Tang, C., 2008. Homocysteine upregulate sresistin production from adipocytes in vivo and in vitro. Diabetes. 57, 817-827. 
[78] Li, Y., Zhang, H., Jiang, C., Xu, M., Pang, Y., Feng, J., 2013. Hyperhomocysteinemia Promotes Insulin Resistance by Inducing Endoplasmic Reticulum Stress in Adipose Tissue. J Biol Chem. 288, 9583-9592.

[79] Morris, M.S., Bostom, A.G., Jacques, P.F., Selhub, J., Rosenberg, I.H., 2001. Hyperhomocysteinemia and hypercholesterolemia associated with hypothyroidism in the third US National Health and Nutrition Examination Survey. Atherosclerosis.155, 195-200.

[80] Saleh, A.A.S., 2015. Lipid profile and levels of homocysteine and total antioxidant capacity in plasma of rats with experimental thyroid disorders. The Journal of Basic \& Applied Zoology 72, 173-178.

[81] Schachter, M., Raziel, A., Friedler, S., Strassburger, D., Bern, O., Ron-El, R., 2003. Insulin resistance in patients with polycystic ovary syndrome is associated with elevated plasma homocysteine. Hum Reprod. 18, 721727.

[82] Sengül, E., Cetinarslan, B., Tarkun, I., Cantürk, Z., Türemen, E., 2004. Homocysteine concentrations in subclinical hypothyroidism. Endocr Res. 30(3), 351-359.

[83] Van Herck, S.L.J., Geysens, S., Bald, E., Chwatko, G., Delezie, E., Dianati, E., Ahmed,
R.G., Darras, V.M., 2013.Maternal transfer of methimazole and effects on thyroid hormone availability in embryonic tissues. Endocrinol. 218, 105-115

[84] Wang, D., Wang, H., Luo, P., Hwang, A., Sun, D., Wang, Y., 2012.Effects of ghrelin on homocysteine-induced dysfunction and inflammatory response in rat cardiac microvascular endothelial cells. Cell Biol Int. 36, 511-517.

[85] Wang, G., Dai, J., Mao, J., Zeng, X., Yang, X., Wang, X., 2005. Folic acid reverses hyperresponsiveness of LPS-induced chemokine secretion from monocytes in patients with hyperhomocysteinemia. Atherosclerosis.179, 395-402.

[86] Yang, N., Yao, Z., Miao, L., Liu, J., Gao, X., Fan, H., Hu, Y., Zhang, H., Xu, Y., Qu, A., Wang, G., 2015. Novel clinical evidence of an association between homocysteine and insulin resistance in patients with hypothyroidism or subclinical hypothyroidism. PLoS ONE 10(5), e0125922.

[87] Yilmaz, N., Pektas, M., Tonguc, E., Kilic, S., Gulerman, C., Gungor, T., 2008.The correlation of plasma homocysteine with insulin resistance in polycystic ovary syndrome.J ObstetGynaecol Res. 34, 384-3

Citation: Ahmed R.G. Maternal Hypothyroidism and Developing Hyperhomocysteinemia.ARC Journal of Nutrition and Growth. 2018; 4(2): 5-9. DOI: dx.doi.org/ 10.20431/2455-2550.0402002.

Copyright: (C) 2018 Authors. This is an open-access article distributed under the terms of the Creative Commons Attribution License, which permits unrestricted use, distribution, and reproduction in any medium, provided the original author and source are credited. 